A pidologie, 1985, 16 (1), 57-68

\title{
MARKING PHEROMONES OF MEGABOMBUS SYLVARUM (L.) AND M. RUDERARIUS (MÜLLER) MALES (HYMENOPTERA : APIDAE)
}

\author{
Günnar BERGSTRöM 1,3), Monica APPELGREN 1, 3), Bo G. SVENSSON 2), \\ Lennart ÅGREN 3), Charles DESCOINS 4), Brigitte FREROT 4), \\ Martine GALLOIS 4), and Martine LETTERE 4)
}

1) Department of Ecological Chemistry, Göteborg University, S - 40033 Göteborg, Sweden

2) Department of Entomology, Uppsala University, $S-75 I 22$ Uppsala, Sweden

3) Uppsala University Ecological Station, $S$ - 38600 Färjestaden, Sweden

4) Laboratoire des Médiateurs Chimiques et Neurobiologie, Equipe de Recherche Associée au C.N.R.S. 070740, Laboratoire des Médiateurs Chimiques, I.N.R.A. Domaine de Brouessy, Magny-les-Hameaux, F 78470 Saint-Rémy-lès-Chevreuse

\section{SUMMARY}

The patrolling behaviours of male Megabombus sylvarum (L.) and $M$. ruderarius (Müller) have been observed. Their labial gland secretions were analysed chemically. The volatile materials, which are probably used as a marking pheromone, were isolated by extraction and then identified by capulary gas chromatograpiny, mass spectrometry and microchemical derivatisatıons. ine inaiur components of the labial glands in $M$. sylvarum are Z-7-hexadecenyl acetate (65\%) and Z-7hexadecenol $(26 \%)$; while the major components in $M$. ruderarius are Z-9-hexadecenol $(67 \%)$ and 7-9-octadecenol ( $9 \%)$.

\section{INTRODUCTION}

In some species of bumblebees, the males exhibit patrolling behaviour (HAas, 1949), i.e. approaching objects along a flight route and marking them with a pheromone produced in the cephalic part of the labial gland (ÄGREN et al., 1979 ; Svensson, 1980 a). In woodland habitats, the species may patrol at different levels above the ground while in treeless areas this spatial segregation is more difficult to achieve. The pheromone-marked spots are regularly patrolled by the males throughout the day and attract virgin females for mating purposes (Awram, 1970 ; Free, 1971; Svensson, 1980 a). 
Since many bumblebee species may co-exist within a limited area, one might ask what premating species-isolating mechanisms have evolved to reduce the risk of interspecific matings. In bumblebee species where the male patrols a flight route, marking pheromones play an important role in premating species isolation. In this investigation, we have studied two bumblebee species : Megabombus sylvarum (L.) and $M$. ruderarius (Müller). They are morphologically similar, patrol at the same time of the year and at the same level above the ground, and are therefore expected to use recognition substances for reproductive isolation.

We report herein the chemistry of compounds found in the labial glands of the two species. Observations on patrolling behaviour in the field are also presented. This report is a continuation of a larger study of marking pheromones in north European bumblebee species (SVEnsson, 1980 b ; Bergström et al., 1981). The chemical analyses and behavioral studies were performed as a co-operative effort between scientists in France and Sweden.

\section{MATERIALS AND METHODS}

\section{Biological naterial}

Megabombus males were collected on the Swedish island of Oland in the Baltic Sea. The cephalic portions of the labial glands were dissected, placed individually into vials containing $0.3 \mathrm{ml}$ hexane for $24 \mathrm{~h}$ and stored at $-20^{\circ} \mathrm{C}$. Bumblebee species were determined th:ough genitalia studies (L $=$ KEN 1973 and ALFORD, 1975). The nomenclature follows Reinig (1981). Individual bumblebees were labelled and placed in a reference collection.

\section{Gas chromatography/Mass spectrometry}

GC analyses were performed on a Hewlett-Packard 5880 A (for the gland extracts and their ozonisation products) and a Hewlett-Packard 588 A (for the epoxides) fitted both with a Superox FA WCOT capillary column $\left(30 \mathrm{~m} ; 0.3 \mathrm{~mm}\right.$ id.) operating at $150^{\circ} \mathrm{C}$ during $5 \mathrm{mn}$ after injection, followed by programming up to $225^{\circ} \mathrm{C}$ at $5^{\circ} / \mathrm{min}$.

GC/MS analyses were performed either on a LKB $2091 \mathrm{GC} / \mathrm{MS}$ or a Finnigan GC/MS with INCOS 2000 data system. GC capillary columns were the same, but longer $(40 \mathrm{~m})$ and were operated under the same conditions.

1 - $3 \mu$ l of the extract or $0.1 \mu \mathrm{g}$ of the standard were injected.

Direct identifications were made by comparisons with reference compounds for mass spectra and GC retention times. These reference compounds were synthetized in the «laboratoire des Médiateurs Chimiques » by original procedures (M. LetTERE Fh. D thesis in preparation).

\section{Ozonisations and epoxidations}

Ozonisations were carried out on a microscale according to BEROZA and BIERL (1967).

Epoxidations of natural compounds were also carried out on a microscale according to KLUN: et al. (1980) with $\mathrm{m}$. chloroperbenzoïc acid in hexane. 
Standards of cis and trans 7,8-epoxy hexadecanols, cis and trans 7,8-epoxy hexadecanyl acetates, cis and trans 9,10-epoxy hexadecanols and cis 9,10-epoxy hexadecanyl acetate were prepared according to the following procedure :

In a three-necked round bottomed flask fitted with a magnetic stirrer, a dropping funnel and a thermometer, we introduced $2.10 \cdots 3$ mole of the corresponding ethylenic precursor dissolved in $50 \mathrm{ml}$ of anhydrous methylene chloride. A solution of $3.10-3$ mole of $\mathrm{m}$. chloroperbenzoïc acid in $25 \mathrm{ml}$ methylene chloride was added dropwise at room temperature. After $3 \mathrm{~h}$ of stirring and one night at room temperature, the reaction mixture was washed with a $10 \%$ sodium hydroxide solution, water and brine. Drying on magnesium sulfate and evaporation of the solvent gave a residue which was distilled or crystallized according to the chemical structure of the required epoxide.

\section{RESULTS}

\section{Chemical analysis}

The GC and GC/MS analyses of extracts of male labial glands were conducted from a single individual of either $M$. sylvarum or $M$. ruderarius.

Typical gas chromatograms are shown in fig. 1-2. In both species, the total amount of volatile material obtained was about $1 \mathrm{mg}$ and consisted mainly of straight chain alcohols, acetates and hydrocarbons.

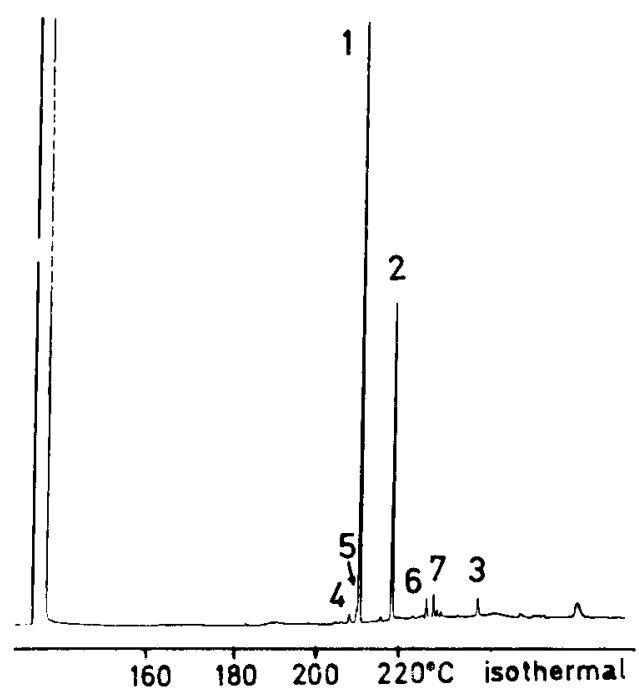

FIG. 1. - Capillary gas chromatogram of a part of a hexane extract of the labial gland from one M. sylvarum male. Analytical conditions given in Material and Methods section.

Numbering of peaks according to Table 1. 


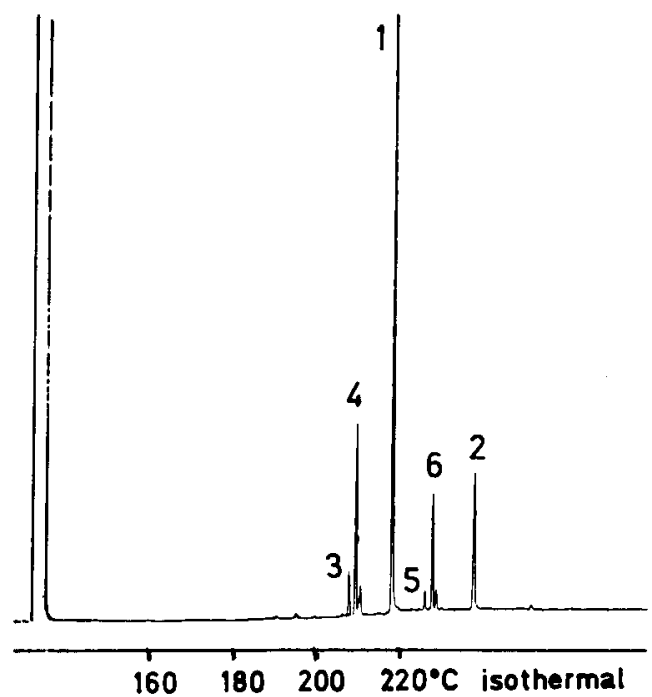

Fig. 2. - Capillary gas chromatogram of a part of a hexane extract of the labial gland from one M. ruderarius male. Analytical conditions given in Material and Methods section. Numbering of peaks according to Table 2.

For $M$. sylvarum, GC analysis showed two main components at the retention times of Z-7 hexadecenyl acetate peak 1 (1) (65\%) and Z-7 hexadecenol peak 2 (2) (26\%), with a third polar compound peak $3(2 \%)$ - probably an octadecenol - and various hydrocarbons $(7 \%)$ including tricosane peak 4 and pentacosane peak 6 (Table 1).

TABL. 1. - Major compounds (larger than $1 \%$ of total volatiles) identified $m$ the labial gland secretion of $\mathrm{M}$. sylvarum males

\begin{tabular}{|c|c|c|c|c|c|}
\hline No & Compound & M & RV & $\% \mathrm{~T}$ & \% LP \\
\hline 1 & Z-7-hexadecenyl acetate & 282 & 2325 & 65 & 100 \\
\hline 2 & Z-7-hexadecenol & 240 & 2409 & 26 & 40 \\
\hline 3 & an octadecenol & 268 & 2635 & 2 & 3 \\
\hline 4 & tricosane & 324 & 2300 & 2 & 3 \\
\hline 5 & tricosenes & 322 & $2318 *$ & 1 & 1 \\
\hline 6 & pentacosane & 352 & 2500 & 2 & 3 \\
\hline 7 & pentacosenes & 350 & $2519 *$ & 2 & 3 \\
\hline
\end{tabular}

\footnotetext{
$* \quad=$ retention value refers to largest unsaturated hydrocarbon.

$\mathrm{M}=$ molecular weight.

$\mathrm{RV}=$ retention value relative to straight chain saturated hydrocarbons.

$\% \mathbf{T}=\%$ of total secretion (components larger than $1 \%$ ).

$\% \mathbf{L P}=\%$ of largest peak.
} 
By $\mathrm{GC} / \mathrm{MS}$, we confirm presence of a $\mathrm{C}_{1 ;}$ monounsaturated acetate $(\mathrm{M} / \mathrm{c}=$ $\left.222\left(\mathrm{M}^{+}-60\right) ; 109 ; 96 ; 82 ; 67 ; 55 ; 43\right)$ and alcohol $(\mathrm{M} / \mathrm{a}=222$ $\left.\left(\mathrm{M}^{+}-18\right) ; 109 ; 96 ; 82 ; 67 ; 55 ; 43\right)$. Other minor compounds are a $\mathrm{C}_{18}$ unsatured alcohol $\left(\mathrm{M} / \mathrm{a}^{2}=250\left(\mathrm{M}^{+}-18\right)\right)$, tricosane $\left(\mathrm{M}^{+}=324\right)$, pentacosane $\left(M^{+}=352\right)$, isomeric tricosenes $\left(M^{+}=322\right)$ and pentacosenes $\left(M^{+}=\right.$ 350). The two $C_{16}$ unsatured compounds were then separated by thin layer chromatography (Kieselgel 60F-254 plates (Merck) eluted with $\mathrm{CHCl}_{3} / \mathrm{C}_{6} \mathrm{H}_{1.1}: 50 / 50$ ) to determine position and geometrical isomerism of the double bond. Ozonolysis of the acetate fraction and subsequent $\mathrm{GC} / \mathrm{MS}$ analysis give two products : Nonanal $(3)\left(\mathrm{M} / \mathrm{e}=142\left(\mathrm{M}^{+}\right) ; 114\left(\mathrm{M}^{+}-28\right) ; 98 ; 82 ; 69\right)$ and 7 -acctoxyheptanal (4) $\left(\mathrm{M} / \mathrm{c}=172\left(\mathrm{M}^{+}\right) ; 144\left(\mathrm{M}^{+}-28\right) ; 129\left(\mathrm{M}^{+}-43\right) ; 112\right.$ $\left.\left(\mathrm{M}^{+}-60\right)\right)$ indicating a 7 -hexadecenyl acetate.

Epoxidation and comparison of the resulting epoxide $(\mathrm{M} / \mathrm{e}=238$ $\left.\left(\mathrm{M}^{+}-60\right) ; 185\left(\mathrm{M}^{+}-\mathrm{C}_{8} \mathrm{H}_{17}\right) ; 155\left(\mathrm{M}^{+}-\mathrm{C}_{8} \mathrm{H}_{1:} \mathrm{O}_{2}\right)\right)$ retention time 21.28') with the two authentic cis and trans 7, 8 epoxy hexadecanyl acetate (5) (retention times respectively $21.27^{\prime}$ and $20.65^{\prime}$ ) by $\mathrm{GC}$ and $\mathrm{GC} / \mathrm{MS}$ indicated a Z-7 double bond in the ethylenic precursor which is in fact Z-7 hexadecenyl acetate as postulated before.

Acetylation of the alcoholic fraction followed by ozonolysis and epoxidation gave the same compound indicating a Z-7 hexadecenol as the natural product. For $M$. ruderarius, GC analysis showed only a major polar compound peak 1 $(67 \%)$ at the retention time of Z-9 hexadecenol (6) and a minor polar compound peak $2(9 \%)$ at the retention time of Z-9 octadecenol (7). Hydrocarbons comprised about $24 \%$ of the volatile material and included also tricosane peak 3 and pentacosane peak 6 (Table 2).

TABL. 2. - Major compounds (larger than $1 \%$ of total volatiles) identified in the labial gland secretion of $\mathrm{M}$. ruderarius males.

\begin{tabular}{|c|c|c|c|c|c|}
\hline No & Compound & $\mathbf{M}$ & RV & $\% \mathrm{~T}$ & $\% \mathrm{LP}$ \\
\hline 1 & Z-9-hexadecenol & 240 & 2413 & 67 & 100 \\
\hline 2 & Z-9-octadecenol & 268 & 2627 & y & 13 \\
\hline 3 & tricosane & 324 & 2300 & 3 & 4 \\
\hline 4 & tricosenes & 322 & $2318^{*}$ & 13 & 19 \\
\hline 5 & pentacosane & 352 & 2500 & 1 & 1 \\
\hline 6 & pentacosenes & 350 & $2520 *$ & 7 & 10 \\
\hline
\end{tabular}

See legend for Table 1 for explanations.

By GC/MS we confirm presence of a $\mathrm{C}_{16}$ and $\mathrm{C}_{18}$ monounsaturated alcohols. $\left(\mathrm{M} / \mathrm{e}=222(\mathrm{M}+-18)\right.$ and $\left.\mathrm{M} / \mathrm{e}=250\left(\mathrm{M}^{+}-18\right)\right)$ and the same hydrocarbons as previously found in $M$. sylvarum. 
The two alcohols were also separated by thin layer chromatography and each one was submitted to ozonolysis (Fig. 3).
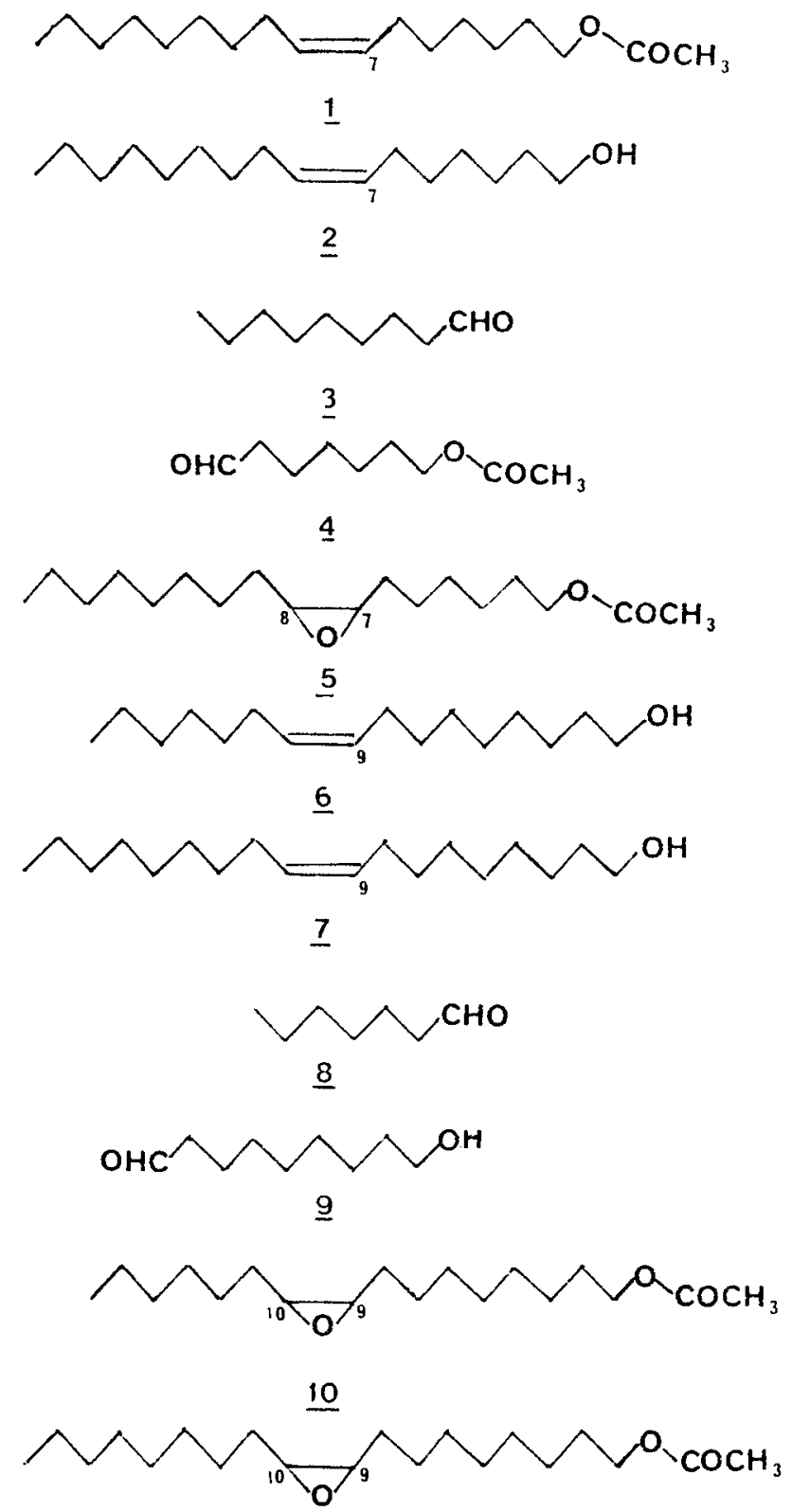

FIG. 3. - Chemical formulae of identified products and their ozonolysis and epoxidation derivatives. 
Ozonolysis of the $\mathrm{C}_{16}$ unsaturated alcohol gave heptanal (8) $(\mathrm{M} / \mathrm{e}=114$ $\left.\left(\mathrm{M}^{+}\right) ; 86\left(\mathrm{M}^{+}-28\right)\right)$ and 9-hydroxy-nonanal $(9)\left(\mathrm{M} / \mathrm{e}=158\left(\mathrm{M}^{+}\right) ; 140\right.$ $\left.\left(\mathrm{M}^{+}-18\right) ; 130\left(\mathrm{M}^{+}-28\right) ; 112\left(\mathrm{M}^{+}-46\right)\right)$ indicating a 9-hexadecenol ; while ozonolysis of the $\mathrm{C}_{18}$ unsaturated alcohol gave nonanal (3) $(\mathrm{M} / \mathrm{e}=142$ $\left.\left(\mathrm{M}^{+}\right) ; 114\left(\mathrm{M}^{+}-28\right) ; 98 ; 82 ; 69\right)$ and the same 9-hydroxy-nonanal $\mathrm{M} / \mathrm{e}=158\left(\mathrm{M}^{+}\right)$indicating a 9-octadecenol.

Determination of the geometrical isomerism of the double bond was achieved by epoxidation on the corresponding acetates. The $\mathrm{C}_{16}$ acetylated epoxide $\left(\mathrm{M} / \mathrm{e}=238\left(\mathrm{M}^{+}-60\right) ; 213\left(\mathrm{M}^{+}-\mathrm{C}_{6} \mathrm{H}_{13}\right) ; 127\left(\mathrm{M}^{+}-\mathrm{C}_{10} \mathrm{H}_{19} \mathrm{O}_{2}\right)\right)$ had the same retention time (21.39') and the same mass spectra as authentic cis 9-10 epoxy hexadecanyl acetate $(10)\left(21.41^{\prime}-20.76^{\prime}\right.$ for the trans isomer). This identified the natural ethylenic precursor as Z-9 hexadecenol. The $\mathrm{C}_{18}$ acetylated epoxide $\left(\mathrm{M} / \mathrm{e}=266\left(\mathrm{M}^{+}-60\right) ; 293\left(\mathrm{M}^{+}-\mathrm{C}_{8} \mathrm{H}_{17}\right) ; 155\left(\mathrm{M}^{+}-\mathrm{C}_{10} \mathrm{H}_{19} \mathrm{O}_{2}\right)\right)$ had the same retention time (29.04') and the same mass spectra as authentic cis 9-10 epoxy octadecanyl acetate (11) (29.04'-28.01' for the trans isomer), indicating a Z-9 octadecenol as the natural compound.
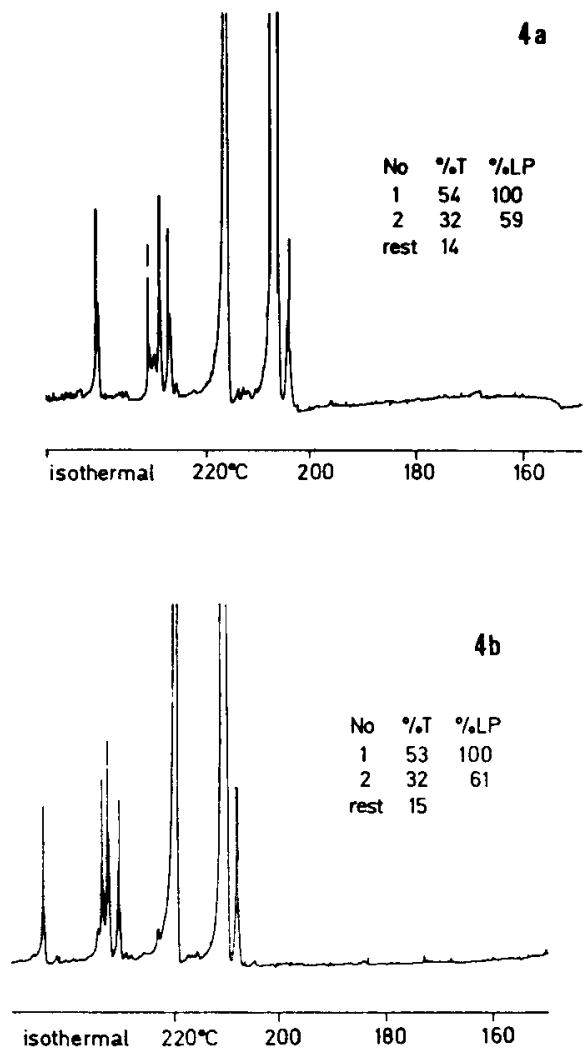

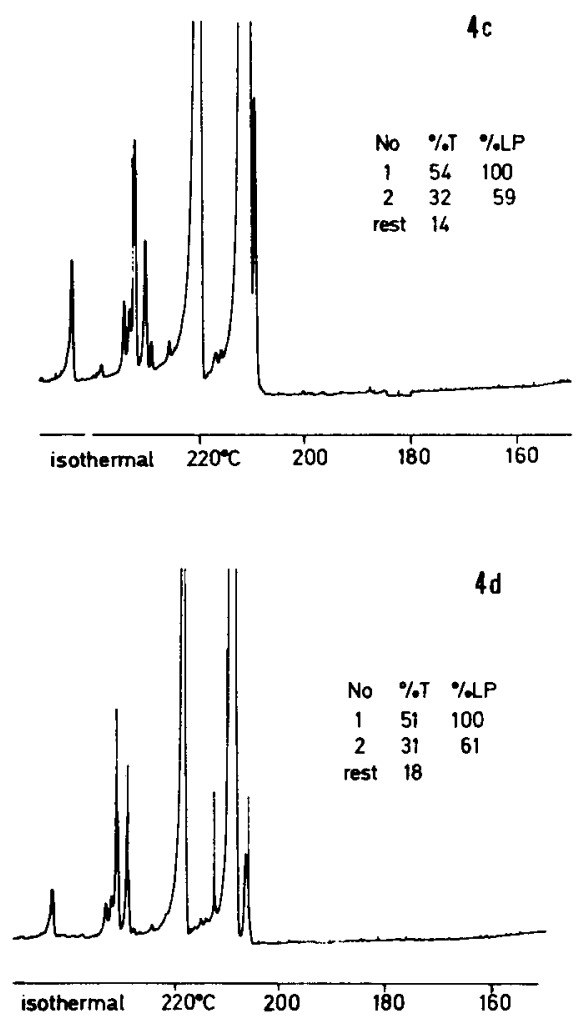

FIG. 4 (a-d). - Capillary gas chromatograms of parts of extracts in hexane of labial glands from four individual M. sylvarum males. Analytical conditions were the same for all four, see Material and Methods section. Numbering of peaks according to Table 2.

For the two species, variation in the quantity of each component and the overall composition of each gland from one individual to the other was very small. This is demonstrated by a series of four individual gas chromatograms presented in fig. 4 a-d for $M$. sylvarum.

\section{Patrolling behaviour}

Males of $M$. sylvarum and $M$. ruderarius were found patrolling in the same areas at the same times together along öland's coastal plains. Their patrolling behavior was similar, i.e., they flew quite slowly and approached the pheromonemarked spots in between tussocks or patches with low vegetation. Spots marked by the two species were sometimes just a few meters apart. Close to the $M$. sylvarum and $M$. ruderarium flight areas, males of Pyrobombus lapidarius (L.) were also observed patrolling without interacting with the other species. The 
latter species was found closer to the shore, approaching dry Rumex stands and single low Rosa bushes. Figure 5 illustrates the distribution of the flight paths for $M$. sylvarum, $M$. ruderarius and $P$. lapidarius. Bombus terrestris (L.) males were also found patrolling in this area.

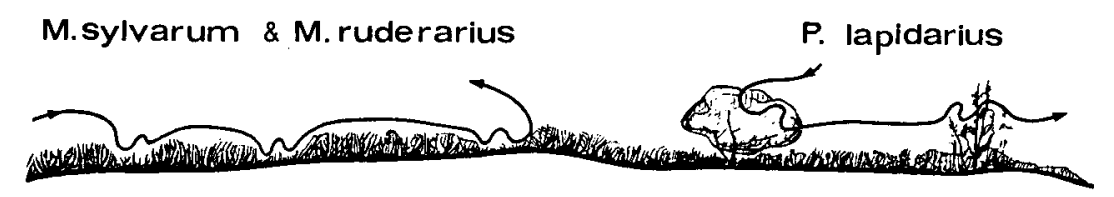

FIG. 5. - Flight path distribution between M. sylvarum, M. ruderarius and P. lapidarius in a coastal area on the Island of Oland.

\section{CONCLUSIONS}

Previous studies have revealed that the composition of male marking pheromones differs greatly among bumblebee species (BERGSTRöm et al., 1981). With regards to morphologically similar species, the chemical composition may be distinctly different, as in Pyrobombus lapponicus (Fabricius) vs. P. monticola (Smith) (Bergström and Svensson, 1973), or very similar as in Alpinobombus alpinus (L.) vs. A. polaris (Curtis) (Svensson and Bergström, 1979). The two species studied here can be regarded as having fairly similar marking pheromones. They fall into a general chemical pattern found throughout the subgenus Thoracobombus of Megabombus (SVENSSON and BERGSTRöm, unpublished). They probably operate as species specific signals. It remains to be seen how precise chemical structure (chain, length, functional group, double bond isomerism) and proportion between components affect species specificity.

However, Megabombus ruderarius and Pyrobombus lapidarius (Kullenberg et al., 1970) exhibit greater similarity in the composition of their marking pheromones. The major component in both species is Z-9-hexadecenol. These species segregate spatially and they are also morphologically separated. As found earlier (Svensson, 1980 a), males of different species which utilize the same environmental space for mating usually differ greatly by virtue of their mechanical (construction of the genitalia) and pheromonal pre-mating species isolating mechanisms. The species studied here also fit into this generalization.

Patrolling behaviour in $M$. ruderarius has been reported previously by many workers (BischofF, 1927 ; HAAS, 1949 ; KRüGER, 1951 and Cumber, 1953). HAAS (1949), KrügER (1951) and BrINGER (1973) have conducted similar investigations with $M$. sylvarum. These authors supply very little data regarding the interactions between the flight-paths of different species. The two species are 
sometimes found to patrol together at a similar height above the ground. However, when possible, Pyrobombus lapidarius patrols at tree top level, separated spatially from the other species. In our study areas where all three species were found flying near each other, $P$. lapidarius chose a different microhabitat.

Electrophysiological studies on the male and female antennae (workers and queens) of the different species must be done to understand how the specific chemicals present in the male labial secretion are recognized at the peripheral level by the sympatric males and the species-specific workers, virgin and old queens.

Received for publication in September 1982. Accepted for publication in October 1984.

\title{
ACKNOWLEDGEMENTS
}

We would like to acknowledge the financial support for this investigation by the Axel and Margaret Ax : son Johnsons's Foundation, the Ekhaga Foundation and I.N.R.A. (Institut National de la Recherche Agronomique). Qualified laboratory assistance has been obtained from Miss Ingela Jonsson and linguistic revision by...

\section{RESUME}

\author{
LES PHEROMONES DE MARQUAGE CHEZ LES MÂLES DE MEGABOMBUS \\ SYLVARUM (L) ET M. RUDERARIUS (MULLER) (HYM. APIDAE)
}

La partie céphalique des glandes labiales des mâles de bourdons produit des composés phéromonaux intervenant dans le comportement de marquage d'un territoire : lieu de rencontre des mâles et des jeunes reines. Le mâle patrouille régulièrement son territoire pour déposer sur les végétaux ces substances odorantes.

Des études antérieures ont montré que la composition chimique de ces phéromones de marquage est propre à chaque espèce de bourdons et qu'elles pouvaient agir comme un facteur d'isolement spécifique. Nous avons donc entrepris dans le cadre d'une collaboration Suède/France l'étude des sécrétions de la partie céphalique des glandes labiales de 2 espèces sympatriques de bourdons qui présentent par ailleurs des similitudes morphologiques et biologiques : Megabombus sylvarum (L.) et Megabombus ruderarius (Müller). Les mâles de ces 2 espèces patrouillent en effet dans leur territoire au même moment de l'année et de la journée, dans des biotopes identiques au même niveau de la strate herbacée.

Les sécrétions des glandes labiales des mâles de ces 2 espèces ont été isolées et les composés majoritaires identifiés par chromatographie en phase gazeuse sur colonne capillaire (Fig. 1, 2, 4), par spectrométrie de masse couplée à la chromatographie en phase gazeuse et par microchimie (ozonolyse et époxidation). La quantité importante de produit contenu dans les glandes $(1 \mathrm{mg} / \mathrm{mâle}$ ) nous a ainsi permis de déterminer la position et la géométrie des doubles liaisons présentes dans les produits identifiés (Fig. 3). Les structures attribuées aux principaux constituants des glandes 
labiales de $M$, sylvarum soint les suivantes : l'Acétoxy-1 héxadécène $7 \mathrm{Z}(65 \%)$ et l'héxadécène-7Z ol-1 (26\%) (Tabl, 1), celles de $M$. ruderarius : l'héxadécène-9Z ol-1 (67\%) et l'octadécène-9Z ol-1 $(9 \%)$ (Tabl. 2). Ces composés, différents d'une espèce à l'autre, doivent intervenir pour assurer la spécificité de la rencontre des sexes à l'intérieur du territoire. Par ailleurs les sécrétions céphaliques de la reine, à action intraspécifique, permettraient au mâle de distinguer une jeune reine vierge fertile d'une reine âgée et fécondée et seraient déterminantes pour la réalisation de l'accouplement à proximité des points marqués dans le territoire. Contrairement aux substances de marquage de territoire à action attractive à distance, la reconnaissance du statut social des reines par les mâles s'effectuerait à courte distance après atterrissage des mâles et contacts antennaires avec l'éventuelle partenaire.

Des études électro-antennographiques au niveau périphérique devraient être poursuivies pour évaluer le degré de reconnaissance des différents constituants des glandes labiales par les différentes castes de la même société de bourdons.

\title{
ZUSAMMENFASSUNG
}

\author{
MARKIERUNGSPHEROMONE BEI MEGABOMBUS SYLVARUM (L.) UND \\ M. RUDERARIUS (MÜLLER) MANNCHEN (HYMENOPTERA : APIDAE)
}

Die cephale Partie der Labialdrüsen der Hummelmännchen produziert Pheromone, die bei der Markierung von Territorien (dem Ort zur Begegnung der Männchen mit den jungen Königinnen) eine Rolle spielen. Die Männchen patrouillieren regelmäßig in ihren Territorien und setzen dabei auf Grünpflanzen Duftmarken ab.

Vorhergehende Studien haben ergeben, daß die chemische Zusammensetzung dieser Markierungspheromone für jede Art spezifisch ist und somit auch als Isolationsmechanismus zwischen den Arten wirken könnte. Wir haben daher im Rahmen einer schwedisch-französischen Zusammenarbeit eine Studie über die Sekretion der cephalen Partie der Labialdrüsen von 2 sympatrischen Hummelarten (Megabombus sylvarum L. und Megabombus ruderarius Müller) angefertigt. Die Männchen dieser beiden Arten patrouillieren zur gleichen Jahres- und Tageszeit in ihren Territorien im gleichen Biotop und auf demselben Niveau der Krautschicht.

Die Sekretionen der Labialdrüsen der Männchen dieser beiden Arten sind isoliert worden und die Hauptkomponenten durch Kapillar-Gaschromatographie (Fig. 1, 2, und 4), durch daran gekoppelte Massenspektrographie und durch Mikrochemie (Ozonolyse und Epoxidation) bestimmt worden. Die meisten Produkte der Drüsen (1 $\mathrm{mg} /$ Männchen) erlaubten auch eine Bestimmung der Position und räumlichen Anordnung der Doppelbindungen der einzelnen Substanzen (Fig. 3). Die Hauptkomponenten des Labialdrüsensekrets sind bei $M$. sylvarum (Tab. 1) : (Z)-7-Hexadecen-1Acetat $(65 \%)$ und (Z)-7-Hexadecen-1-ol (26\%), bei $M$. ruderarius (Tab. 2) : (Z)-9-Hexadecen-1-ol $(67 \%)$ und (Z)-9-Oktadecen-1-ol ( $9 \%$ ). Diese Komponenten, die sich von Art zu Art unterscheiden, müssen als Isolationsmechanismus wirken, so daß die Begegnung der Geschlechter einer Art innerhalb des Territoriums gesichert ist. Andererseits ermöglicht die cephale Sekretion der Königin als intraspezifische Aktion den Männchen die Unterscheidung zwischen einer jungen, unbegatteten und einer alten, begatteten Königin und könnte Auslöser sein für den Vollzug der Begattung in der Nähe der Markierungsstellen im Territorium. Im Gegensatz zu den Markierungssubstanzen, die auf Distanz wirken, erfolgt die Erkennung des Zustands der Königin durch die Männchen auf kurze Entfernung, und zwar nach der Landung durch Aufnahme von Fühlerkontakt mit dem eventuellen Partner.

Die elektroantennographischen Studien auf peripherem Niveau sollten fortgesetzt werden, um den Grad der Erkennung der Sekrete aus den Labialdrüsen durch die verschiedenen Kasten aus đer Sozietät der Männchen zu erfassen. 


\section{LITTERATURE}

Ågren L., Cederberg B. and Svensson B.G., 1979. - Changes with age in ultrastructure and pheromone content of male labial glands in some bumblebee species (Hymenoptera, Apidae), Zoon, 7, 1-14.

Alford D.V., 1975. - Bumblebees, Davis Poynter, London.

Awram W.J., 1970. - Flight route behaviour bumblebees, Ph. D. Thesis, University of London,

Bergström G. and Svensson B.G., 1973. - Studies on natural odoriferous compounds. VIII. Characteristic marking secretions of the forms lapponicus and scandinavicus of Bombus lapponicus Fabr. (Hymenoptera, Apidae). Chem. Scripta, 4, 231-238.

Bergström G., Svensson B.G., Appelgren M. and Groth I., 1981. - Complexity of bumblebee marking pheromones : Biochemical, ecological and systematical interpretations. In : systematics association, Special volume. $\mathrm{N}^{\circ} 19$, «Biosystematics of Social Insects》, Edited by P.E. Howse, 1981, Academic Press.

Beroza M. and Bierl A.B., 1967. - Rapid determination of olefin position in organic compounds in the microgram range by ozonolysis and gas chromatography. Anal. Chem., 39, 1131-1135.

Bischoff H., 1927. - Biologie der Hymenopteren. Springer, Berlin, pp. 598.

Bringer B., 1973. - Territorial flight of bumblebee males in coniferous forest on the northernmost part of the island of öland. Zoon, suppl., 1, 15-22.

Cumber R.A., 1953. - Some aspects of the biology and ecology of bumblebees bearing upon the yields of red-clover in New Zealand. N.Z.J. Sci. Technol., B 34, 227-240.

FREE J.B., 1971. - Stimuli eliciting mating behaviour in bumblebee Bombus pratorium L. males. Behaviour, 40, 55-61.

HaAs A., 1949. - Arttypische Flugbahnen von Hummelmännchen. Z. vgl. Physiol., 31, 281-307.

Krüger E., 1951. - Über die Flugbahnen der Männchen der Gattungen Bombus and Psithyrus. Z. Tierpsychol., 8, 61-75.

Kullenberg B., Bergström G. and Ställberg-Stenhagen S., 1970. - Volatile components of the cephalic marking secretions of males bumblebees. Acta Chem. Scand,, 24, 1481-1483.

LoKEN A., 1973. - Studies on scandinavian bumblebees (Hymenoptera, Apidae). Nor. Ent. Tidskr., 20, 1 -218.

Pers van Der J.N.C., 1981. - Comparison of electroantennogram response spectra to plant volatiles in seven species of Yponomeuta and in the tortricid Adoxophyes orana. Ent. exp. \& appl. 30, $189-192$.

Priesner E., 1968. - Die interspezifischen Wirkungen der Sexuallockstoffe der Saturniidae (Lepidoptera). Z. vgl. Physiol. 61, 263-297.

Reinig W.F., 1981. - Synopsis der in Europa nachgewiesenen Hummel- und Schmarotzerhummelarten (Hymenoptera, Bombidae). Spixiana (München), 4, 159-164.

Svensson B.G. and Bergström G., 1979. - Marking pheromones of Alpinobombus males (Hymenoptera, Apoidae, Bombinae). J. Chem. Ecol., 5, 603-615.

Svensson B.G., 1980 a. - Patrolling behaviour of bumblebee males in subalpine/alpine area, Swedish Lapland. Zoon, 7, 67-94.

Svensson B.G., 1980 b. - Species isolating mechanisms in male bumblebees (Hymenoptera, Apidae). Abstr. Upps. Diss. Fac. Sci., 549, 1-42. 